Article

\title{
Global Importance of Indigenous and Local Communities' Managed Lands: Building a Case for Stewardship Schemes
}

\author{
Kamaljit K. Sangha
}

Research Institute for the Environment and Livelihoods, Charles Darwin University, 0810 Darwin, NT, Australia; kamaljit.sangha@cdu.edu.au

Received: 7 August 2020; Accepted: 17 September 2020; Published: 23 September 2020

\begin{abstract}
The role of Indigenous peoples and local communities (IPLCs) in sustainably using and managing natural resources is becoming broadly recognised within some international platforms (e.g., the UN Permanent Forum on Indigenous Issues and Intergovernmental Platform on Biodiversity and Ecosystem Services). However, the support for IPLCs to continue managing their land is either completely absent or scanty. This paper presents the value of only four ecosystem services, estimated at USD 1.16 trillion per year, that are delivered from IPLCs managed lands alone (excluding coastal, marine, and other resources). These four ecosystem services (ES), i.e., carbon sequestration, biocontrol, air, and water regulation offer offsite benefits to the wider regional and global populations yet without returns to the IPLCs themselves except for facing more climate and natural disaster-related challenges mainly caused by the actions of mainstream society. It further outlines key challenges and advocates for establishing stewardship mechanisms to promote and support IPLCs land management practices that will effectively help in protecting and preserving biodiversity, water, and other natural resources on Earth to sustain and enhance human well-being.
\end{abstract}

Keywords: Indigenous peoples and local communities (IPLCs); natural resources; ecosystem services; payments for ecosystem services (PES); indigenous land management; stewardship arrangements

\section{Introduction}

Globally, millions of Indigenous peoples and local communities (IPLCs) live in harmony with nature. They use and care for nature's resources to obtain their livelihoods and many socio-cultural values that support the rich diversity on Earth. Recognising IPLCs' low impact and sustainable living, the United Nations suggested the need to support and maintain Indigenous ways of life, describing, "Indigenous peoples are inheritors and practitioners of unique cultures and ways of relating to people and the environment..." [1] However, to date, there is little awareness and acknowledgement of IPLCs' efforts to preserve nature and/or of their abilities to astutely use nature's resources that contribute to delivering many environmental benefits for the wider regional and global public. In contrast, the actions of wider mainstream society have made many IPLCs much more vulnerable to natural disasters such as climate change in the recent decades, as evident from a wide range of media resources including migration of many island communities across the Asia-Pacific [2-4].

The term 'Indigenous peoples and local communities' (IPLCs) is used here following the United Nations-Indigenous Peoples and Intergovernmental Panel on Biodiversity and Ecosystem Services (IPBES), for recognizing peoples' historic connections with land and the natural environment, their unique cultures and traditions.

There are 2.5 billion people of Indigenous and local origin worldwide, of whom 370 million are Indigenous living across 90 countries and representing about 5000 cultures [5,6]. IPLCs manage about 
$50 \%$ of the global landmass, most of which is managed communally $[7,8]$. However, Indigenous peoples have legal ownership rights to a mere $10 \%$ and further management rights to another $8 \%$ of the total area [7]. A recent land area analysis by Garnett et al. [9] reveals that among the IPLCs, Indigenous peoples alone manage about 38 million $\mathrm{km}^{2}$ of land across all the continents, covering a diverse range of ecosystems such as savannas, forests, tropical forests, shrublands and rangelands.

The importance of natural resources for supporting our economies and human well-being is highlighted mainly after the 1990s by many ecologists and ecological economists including a few world-known economists [10-15], however, the uptake of embracing nature as a foundation for supporting human well-being and economies in policy arena has been poor to date. On the contrary, the consequences of mismanaging natural resources and their devastating impacts on human well-being, economies, the number of people impacted, and magnitude of those impacts, particularly due to floods, droughts and wildfires, are increasing rapidly both in intensity and scale [16]. In this current situation, worldwide recognition is required of the role of IPLCs for protecting biodiversity, water, and other natural resources that support life on Earth.

This article outlines the role of IPLCs in managing natural resources while building a case for developing stewardship mechanisms, if we, as a society, realistically want to protect natural resources in this Anthropocene era. This paper further suggests establishing appropriate support mechanisms (financial and non-financial) to continue maintaining environmental benefits for the wider public [7,17]. Such mechanisms can promote IPLCs land management for preserving and protecting natural resources at the local, regional, and global scales while exerting much less pressure on natural resources compared to the majority of the mainstream population.

\section{Role of Indigenous and Local Communities in Managing Natural Resources}

Deforestation rates are much lower on IPLCs managed lands compared to any other land uses across the globe $[7,18]$. A key benefit of IPLCs managed lands is the provisioning of a range of ecosystem services (ES) — the benefits people drive from nature - not just for the locals but also for the regional and global human populations [17]. A relatively low-resource dependent lifestyle practised by IPLCs involving astute management, limited use of natural resources, and applying integrated knowledge helps in conserving natural resources. It ensures the delivery of many ES such as the provisioning of good air and water, protecting biodiversity, abating and sequestering greenhouse gas emissions, maintaining and regulating water and climate cycles, and supporting soil and other ecological processes to support life on Earth.

Many IPLCs have a two-way relationship with their lands, and peoples' customs and ceremonies are intricately connected to the land, comprising as part of their living. For example, in northern Australia, Indigenous peoples have a two-way relationship with their land, and they often call their traditional land 'country'. They consider themselves as 'the custodians of traditional [clan] land [not the owners]' and often express sayings like 'my country is sick, I'm sick'. This is in contrast to the ownership view prevalent among the mainstream human population (Table 1). An integrated relationship between IPLCs and their traditional lands has led to an evolution of peoples' customs and ceremonies over time that include caring for country as a key principle, which equates to modern environment management practices, as explained in Figure 1. The world views of IPLCs concerning spiritual life, land, connectedness with nature, learning, and managing their traditional lands are quite in contrast to the mainstream society, which probably lay the foundation of IPLCs' profound connectedness with nature (Table 1). 


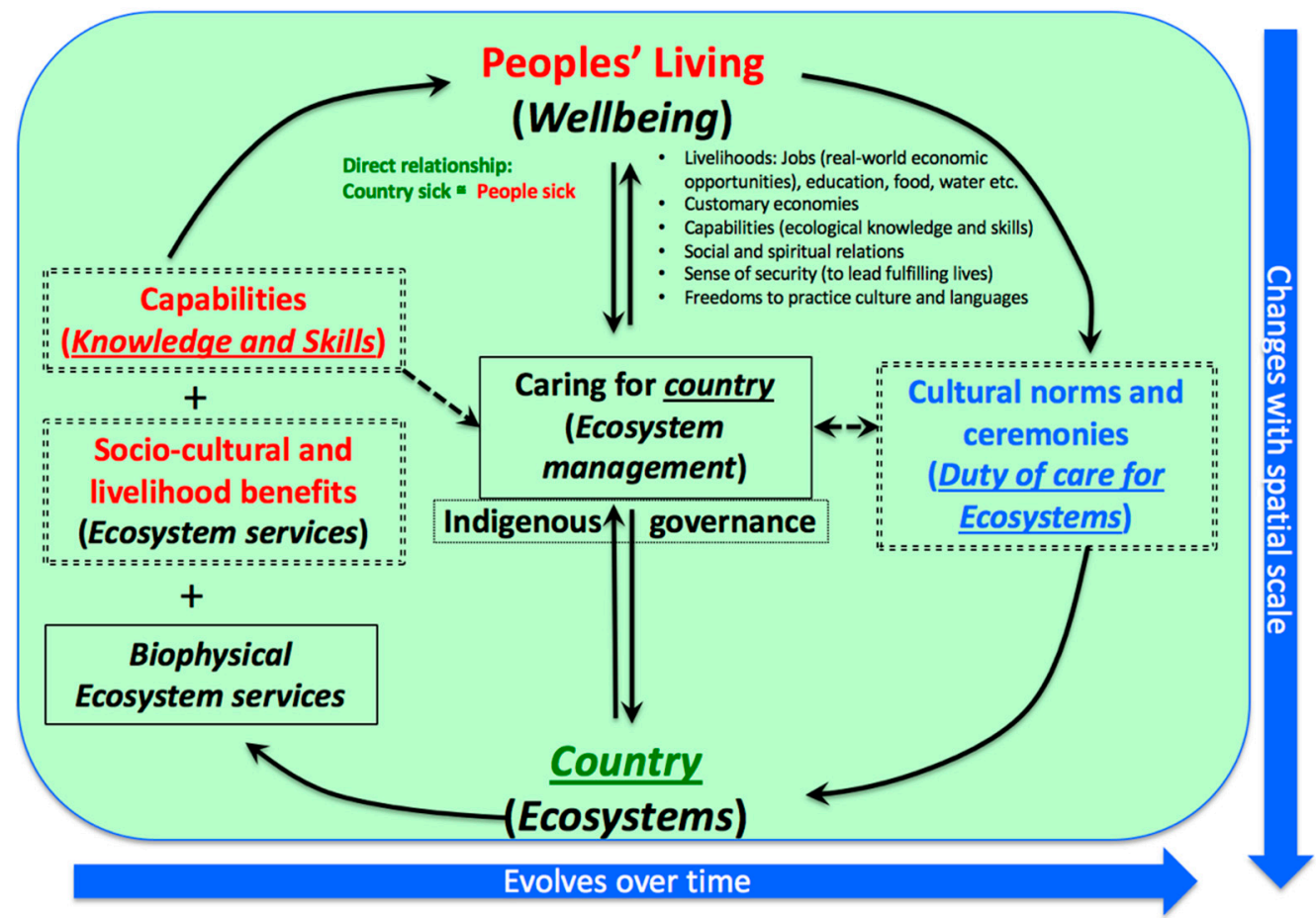

Figure 1. An Indigenous framework for demonstrating connections with country. The green box denotes country of which people and their living are an integral part (thus, red and green text are not enclosed in a box). People derive socio-cultural, livelihoods, and other benefits including their capabilities from being connected with country, not in isolation. In each text box, the normal font indicates Indigenous, and the italicized equivalent indicates Western perspectives (except for country). The arrows denote the influence (benefits/knowledge) between the two systems. The blue arrows at the base and on the side reflect changes in peoples-country associations over temporal and spatial scales. (Source: Sangha and Russell-Smith [19]).

Table 1. World views of Indigenous vs. Western society [17,20-22].

\begin{tabular}{|c|c|c|}
\hline & Indigenous Society & Western/Contemporary Society \\
\hline Spiritual views & Strongly spiritually oriented. & $\begin{array}{l}\text { Scientific, requiring proof for } \\
\text { spiritual belief. }\end{array}$ \\
\hline Connectedness & $\begin{array}{l}\text { Everything, living and non-living, } \\
\text { is connected, and identity comes } \\
\text { from connectedness. }\end{array}$ & $\begin{array}{l}\text { Compartmentalised values, with } \\
\text { isolated 'silo' systems approach. }\end{array}$ \\
\hline Land & $\begin{array}{l}\text { Sacred, usually believed to be } \\
\text { created by the supreme spiritual } \\
\text { beings. }\end{array}$ & $\begin{array}{c}\text { Land is considered a resource, } \\
\text { and often its resources are } \\
\text { extracted for the } \\
\text { development/human purposes. }\end{array}$ \\
\hline Time & $\begin{array}{l}\text { Cyclical, nature's processes are } \\
\text { central to the time domain. }\end{array}$ & $\begin{array}{l}\text { Linear, man-made targets are } \\
\text { central to the time domain. }\end{array}$ \\
\hline Human being & Part of nature. & Most important in the world. \\
\hline Education or learning & $\begin{array}{l}\text { Focus on on-ground learning, with } \\
\text { on-going training from the Elders } \\
\text { as teachers. }\end{array}$ & $\begin{array}{l}\text { Focus on theoretical and practical } \\
\text { knowledge obtained in formal } \\
\text { settings (educational institutes). }\end{array}$ \\
\hline
\end{tabular}

\section{Public Environmental Benefits from IPLCs' Effective Land Management}

An area of 38 million $\mathrm{km}^{2}$ of traditional estate managed by the Indigenous peoples without exploiting resources to maximize production-a typical practice among the mainstream 
society-delivers a wide range of benefits to the wider regional and global public. These benefits include abating greenhouse gas emissions, sequestering carbon, supporting the diversity of species, regulation of water and climate cycles, and continuing IPLCs' spiritual and cultural practices for futures generations to learn.

Using TEEB (The Economics of Ecosystems and Biodiversity) database of ES, the monetary values of four key ES i.e., carbon sequestration, air quality, maintaining water cycles, and biocontrol, were estimated for the IPLCs managed land area of 38 million $\mathrm{km}^{2}$ covering tropical forests, woodlands, and grasslands. Two scenarios were used: i. $50 \%$ of the total area delivers four key ES; ii. $25 \%$ of the total area delivers those ES. The value of the four ES is estimated at USD 1.16 trillion per year under scenario (i), or USD 583 billion per year under scenario (ii) (Table 2). Here, only four listed ES i.e., $\mathrm{C}$ sequestration, maintaining air, the water cycle, and biocontrol were evaluated because these services directly contribute to offsite benefits, extending beyond the local, to regional and global scales.

Table 2. Estimated value of ES from indigenously managed land of 38 million $\mathrm{km}^{2}$ area, applying two scenarios: i. $50 \%$ of the area managed effectively to deliver ecosystem services (ES); and ii. $25 \%$ of the area managed effectively to deliver these ES.

\begin{tabular}{ccc}
\hline $\begin{array}{c}\text { Value of ES in Million USD } \\
\text { [all Values in 2020] }\end{array}$ & $\begin{array}{c}\text { 50\% of Indigenously } \\
\text { Managed Land Delivering ES }\end{array}$ & $\begin{array}{c}\text { 25\% of Indigenously } \\
\text { Managed Land Delivering ES }\end{array}$ \\
\hline C sequestration ${ }^{1}$ & $1,102,000$ & 551,000 \\
\hline Air quality & & 12,673 \\
\hline Maintaining water cycle $^{3}$ & 25,346 & 7758 \\
\hline Biocontrol $^{4}$ & 15,516 & 11,736 \\
\hline Total in million USD $^{2}$ & 23,473 & 583,167 \\
\hline
\end{tabular}

${ }^{1} \mathrm{C}$ sequestration: the value was estimated using an average conservative rate of $\mathrm{C}$ sequestration at 100 tonnes per ha in tropical woodlands (IPCC 2000), at a rate of USD 10/tonne of C. 2,3,4 were estimated using the Economics of Ecosystems and Biodiversity (TEEB) database [23], applying tropical and subtropical case studies. An average value of USD 13.34/ha for air quality; USD 8.16/ha for maintaining water cycles; and USD 12.35/ha for biocontrol services were applied.

It is important to note that the estimates presented in Table 2 exclude land managed by the local communities who largely apply sustainable livelihood and agricultural practices without intensive use of pesticides, fertilizers, or exploiting water and land resources. Moreover, many cultural and spiritual services are beyond any price tag, but they are paramount for IPLCs to practice and learn their cultural norms, ceremonies, languages, and many other aspects of traditional living. The value of such services and the role that these services play in the well-being of IPLCs is well beyond the estimated values presented in Table 2.

\section{An Overview of the Current Situation of IPLCs Land Affairs and Available Support through Global Platforms}

To date, many governments in developing and developed countries have either infringed upon or suppressed IPLCs related lands to support and advance development for the mainstream society $[6,24]$. This has caused serious ongoing impacts on IPLCs including forced relocations and abandoning the ancestral lands with perpetual social, economic, and cultural impacts [6,7].

Worldwide, there is a serious lack of actions to protect IPLCs' rights and access to land, which underpins peoples' way of life $[6,7,24]$. As mentioned earlier, IPLCs managed lands deliver many ES benefits, which are beyond monetary measures, for the wider public, but often an understanding of such benefits among the public and policy sector is missing due to emphasis on mainstream economic activities. This indicates the degree of ignorance prevailing among the decision-makers and the general public about the importance of IPLCs managed lands.

Recognition of IPLCs and their lands has improved a little over the last few years at the global front. International platforms such as the UNPFII [25] offers advice on Indigenous issues to the UN 
Economic and Social Council and through the Council to the UN agencies, funds, and programmes. The International Work Group for Indigenous Affairs (IWGIA) is a human rights organisation based in Denmark that also promotes, protects, and defends Indigenous peoples' rights. Several regional, national, and local organisations and non-government organisations (NGOs) such as Survival International, Indigenous Peoples' Council on Bio-colonialism, and Amazon Conservation Team all help raise awareness about Indigenous issues. Yet, there are only a handful of organisations given 370 million Indigenous people and their spread across 90 nations. In addition, there are $>500$ millions of local communities across the globe who predominantly live in rural areas, in close relationship with their lands mainly practising sustainable agriculture, for whom there are no specific organisations or platforms at the international or regional scales to represent their concerns at the global scale in forums such as IPBES and the UN agencies.

Due to widespread concerns for climate change and biodiversity over the last 1-2 decades, environmental scientists have been at the forefront to recognise Indigenous efforts. The global platforms such as IPBES, International Union for Conservation of Nature (IUCN), and Conservation of Biological Diversity (CBD) have established IPLCs working groups. Within the UN, there is a wider recognition of the IPLCs' role as protectors of biodiversity and as key actors for the implementation of sustainable development and land management, but this is not the same for local communities. The UN Declaration on the Rights of Indigenous Peoples (UNDRIP 2007) [26] further endorses the need to respect Indigenous rights under Article 25: Indigenous peoples have the right to maintain and strengthen their distinctive spiritual relationship with their traditionally owned or otherwise occupied and used lands, territories, waters, coastal seas, and other resources and to uphold their responsibilities to future generations in this regard. However, the adoption and support for such principles depend on the state and/or local governments, which have been very limited to date. Such support and recognition should also be extended to local communities, comprising $>2$ billion people, who are widespread across the globe, cultivating lands in a sustainable manner applying traditional practices and norms, and using much fewer external inputs-contributing significantly to protecting biodiversity in the agricultural landscapes.

\section{Challenges to Recognise Indigenous Peoples and Local Communities Role in Managing Natural Resources}

At the time of writing this article, coronavirus (COVID-19) has dominated the world, spreading at an unprecedented rate across countries from all the continents, leaving governments and the public in despair. Globalisation has delivered many benefits but at a huge cost to the local economies, ecosystems, and communities. This catastrophe reminds us of reconsidering our priorities for: $i$. what kind of economy we want; and ii. how to be resilient and self-reliant in such tumultuous times.

Conversely, many IPLCs have survived the political, developmental and ecological crisis, and offer some important lessons to the rest of the world to consider holistic and integrated development in the future [22,27]. Without doubt, our key lessons should include a much stronger focus on sustainable local economies for enhancing human well-being while living in harmony with nature, along with building community resilience. There is a need to consider both monetary and non-monetary benefits of effectively managing lands in order to appropriately inform policy decision-makers on sustainable development. Such efforts will ensure protecting the biodiversity of nature that contributes directly and indirectly to our economies and well-being [28].

To date, our modern economic approaches largely overlook the role that many IPLCs play in astutely using and managing traditional lands that deliver many ES [7,16,17,22,27]. Importantly, IPLCs' knowledge, skills, and capabilities are linked to their traditional systems, including their knowledge of managing land. Underestimating the value of their land management further leads to misinformed policies and programs that mostly target at mainstreaming IPLCs into the contemporary economies [29]. Lack of appropriate tools and measures to account for non-monetary benefits, such as biodiversity or water regulation that 
flow from sustainably managing lands contributes largely to mislead policy decision-making that typically focus on utilitarian values with monetary estimations [10,12,13].

To appropriately understand the 'true value' of IPLCs' contributions for effectively and sustainably managing traditional lands and to incorporate those values into decision-making is a key challenge [21,22,27]. However, a proper consideration of such values into policy decision-making is essential. Such an approach can deliver multiple benefits for enabling IPLCs to live the lives they want to live, in line with the development argument by the Economics Nobel Laureate, Prof Amartya Sen [30]. He argues that 'development' is about enabling people to achieve their functionings so they can lead the lives the way they want [30]. To do so, government and non-government organisations should recognise peoples' capabilities and offer them the right opportunities. At present, typical contemporary economics/development approaches require serious consideration of: 1 . Indigenous worldviews (IPLCs perspective of development); 2 . understanding of the 'true' value of IPLCs managed lands; 3 . The application of multiple monetary and non-monetary approaches. Such an integrated understating will appropriately inform policy decision-makers to develop the right opportunities for enabling IPLCs, applying a two-way approach, as shown in Figure 2.

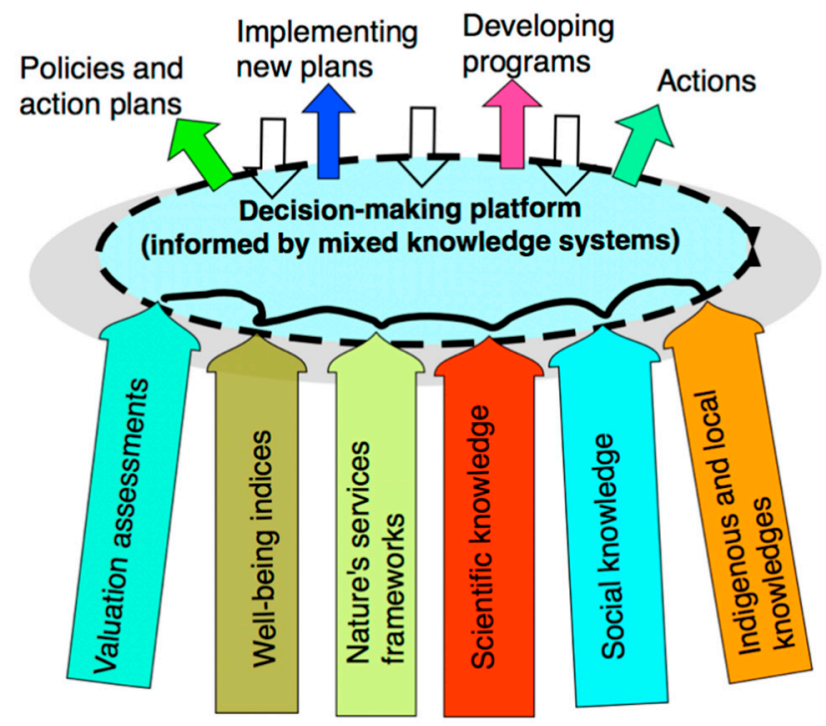

Figure 2. Diverse knowledge systems, represented as 'pillars', to inform decision-making and appropriate policy choices following two-way flows of information (Source: Sangha [21]).

\section{Conclusions}

Recognising IPLCs' role in managing natural resources and the value of their contributions towards ES for the regional and global populations is essential to continue conserving natural resources and obtaining environmental benefits. Assessing the monetary value of only four ES from Indigenously managed lands, estimated between USD 1.16-USD 0.583 trillion per year, suggests that the total, including monetary (production of crops, bush food, and medicine) and non-monetary benefits such as cultural and spiritual values that are vital for peoples' well-being, are much greater. The total global value of 17 ES from 16 biomes is estimated at USD 125 trillion per year [11]; and accounting for only four ES from Indigenous lands alone (excluding coastal, marine, and other resources) comprises $1 \%$ of that total ES value. Yet, the IPLCs obtain little or no benefit or even proper recognition for their contributions to maintaining ES that benefit the wider public. This paper highlights the importance of enabling IPLCs to manage their land effectively for maintaining a continuous flow of ES for the local and greater public benefit.

To do so, we need to develop support mechanisms including respecting IPLCs' rights and access to land and appropriate financial instruments such as Payments for ES (PES) (as advocated by several experts $[21,31,32])$. The importance of such schemes is recently being acknowledged by the world-known 
economist Prof Partha Das Gupta in a recent report on 'the Economics of Biodiversity' [33]. Under PES arrangements, typically the beneficiary pays the service provider. However, for the IPLCs managed lands, the wider public is the main beneficiary, and therefore requires specific indigenously designed PES mechanisms that go beyond geographical boundaries. For this interlinked state, regional and global platforms need to be established that make each state government accountable for looking after the IPLCs land management matters, and affording financial support for the IPLCs to continue applying conservative practices.

To protect biodiversity and mitigate climate change, IPLCs natural resource management practices and knowledge offers credible solutions in this Anthropocene era. In Australia, the government-funded 'Working on Country' program offers a good example where Indigenous peoples living across the tropical savannas manage their traditional lands to protect biodiversity and other natural resources while practising their traditional norms and ceremonies [34]. The program currently offers employment for $>830$ rangers in remote locations where there are few economic opportunities. Moreover, it delivers several socio-economic and health benefits for Indigenous people and enables them to learn and practice their traditional knowledge and to lead lives the way they want [35]. There are several examples across the globe but mostly at small, local scales [36].

An integrated but collective global effort with targeted regional, state, and local scale approaches is necessary to both support IPLCs and protect the environment. Such an initiative will further help addressing various UN-led Sustainable Development Goals for millions of people, particularly for reducing poverty; enhancing good health and well-being; supporting direct work and economic growth; reducing inequalities; developing sustainable cities and communities; and climate action [37]. However, from the IPLCs perspective it is important to redefine 'economic growth' by applying Sen's concept of development for enabling people to lead the lives they want to live. Stewardship arrangements can afford direct work and development opportunities, as well as enhance IPLCs' well-being and resilience [30]. Application of appropriately developed PES schemes rewarding IPLCs for promoting sustainable use of resources is a feasible, rational, economic approach for development [38]. Most importantly, it will help us all, as a human society, to be resilient, particularly in the serious crises that humanity is facing now.

Funding: This research received no external funding.

Acknowledgments: The author is thankful to the Bushfire \& Natural Hazards CRC, Australia, for supporting the over-arching project on building resilience of remote Indigenous communities.

Conflicts of Interest: The author declares no conflict of interest.

\section{References}

1. The United Nations. Indigenous Peoples. Department of Economics and Social Affairs. 2019. Available online: https://www.un.org/development/desa/indigenouspeoples/about-us.html (accessed on 11 February 2019).

2. Herman, D. What Climate Change Will Mean for the People of Oceania. National Geographic 27 March 2015. Available online: https://www.smithsonianmag.com/smithsonian-institution/what-climate-change-meansfor-people-of-oceania-180954775/\#dbXwR1pTScYomAjb.99 (accessed on 12 April 2020).

3. Shiva, V. Earth Democracy: Justice, Sustainability and Peace; ZED Books Ltd.: London, UK, 2016.

4. Wing, T. Submerging Paradise: Climate Change in the Pacific Islands; Climate Institute: Washington, DC, USA, 2017; pp. 1-16.

5. Reytar, K.; Veit, P. 5 Maps Show How Important Indigenous Peoples and Local Communities Are to the Environment; World Resources Institut: Washington, DC, USA, 2017. Available online: https://www.wri.org/print/57261 (accessed on 15 June 2020).

6. Berger, D.N. The Indigenous World 2019; The Authors and The International Work Group for Indigenous Affairs: Copenhagen, Denmark, 2019.

7. Notess, L.; Veit, P.G.; Monterroso, I.; Sulle, A.E.; Larson, A.M.; Gindroz, A.-S.; Quaedvlieg, J.; Williams, A. The Scramble for Land Rights: Reducing Inequity between Communities and Companies; World Resources Institute (WRI): Washington, DC, USA, 2018. 
8. World Resources Institute (WRI). Various Reports and Projects on Ecosystem Services. 2019. Available online: https://www.wri.org (accessed on 1 November 2018).

9. Garnett, S.T.; Burgess, N.D.; Fa, J.E.; Fernández-Llamazares, Á.; Molnár, Z.; Robinson, C.J.; Watson, J.E.M.; Zander, K.K.; Austin, B.; Brondizio, E.S.; et al. A spatial overview of the global importance of Indigenous lands for conservation. Nat. Sustain. 2018, 1, 369-374. [CrossRef]

10. Costanza, R.; D'Arge, R.; de Groot, R.; Farber, S.; Grasso, M.; Hannon, B.; Limburg, K.; Naeem, S.; O’Neill, R.V.; Paruelo, J.; et al. The value of the world's ecosystem services and natural capital. Nature 1997, 387, 253-260. [CrossRef]

11. Costanza, R.; de Groot, R.; Sutton, P.; van der Ploeg, S.; Anderson, S.J.; Kubiszewski, I.; Farber, S.; Turner, R.K. Changes in the global value of ecosystem services. Glob. Environ. Chang. 2014, 26, 152-158. [CrossRef]

12. Costanza, R.; Kubiszewski, I.; Giovannini, E.; Lovins, H.; McGlade, J.; Pickett, K.E.; Ragnarsdóttir, K.V.; Roberts, D.; Vogli, R.D.; Wilkinson, R. Development: Time to leave GDP behind. Nature 2014, 505, 283-285. [CrossRef]

13. Daly, H.E. Beyond Growth: The Economics of Sustainable Development; Beacon Press: Boston, MA, USA, 1996.

14. Daily, G.C. Nature's Services: Societal Dependence on Natural Ecosystems; Island Press: Washington, DC, USA, 1997.

15. Daly, H. Economics in a Full World. Sci. Am. 2005, 293, 100-107. [CrossRef] [PubMed]

16. IPBES (Intergovernmental Platform on Biodiversity and Ecosystem Services). Summary for Policymakers of the Global Assessment Report on Biodiversity and Ecosystem Services. 2019. Available online: https: //www.ipbes.net/news/ipbes-global-assessment-preview (accessed on 17 May 2020).

17. Sangha, K.K.; Maynard, S.; Pearson, J.; Dobriyal, P.; Badola, R.; Hussain, S.A. Recognising the role of local and Indigenous communities in managing natural resources for the greater public benefit: Case studies from Asia and Oceania region. Ecosyst. Serv. 2019, 39, 100991. [CrossRef]

18. Rights and Resources Initiative. Who Owns the World's Land? A Global Baseline of Formally Recognized Indigenous and Community Land Rights; WRI: Washington, DC, USA, 2015.

19. Sangha, K.; Russell-Smith, J. Towards an Indigenous Ecosystem Services Valuation Framework: A North Australian Example. Conserv. Soc. 2017, 15, 255-269.

20. Stocker, L.; Collard, L.; Rooney, A. Aboriginal world views and colonisation: Implications for coastal sustainability. Local Environ. 2016, 21, 844-865. [CrossRef]

21. Sangha, K.K.; Russell-Smith, J.; Costanza, R. Mainstreaming indigenous and local communities' connections with nature for policy decision-making. Glob. Ecol. Conserv. 2019, 19, e00668. [CrossRef]

22. Sangha, K.K.; Preece, L.; Villarreal-Rosas, J.; Kegamba, J.J.; Paudyal, K.; Warmenhoven, T.; RamaKrishnan, P.S. An ecosystem services framework to evaluate Indigenous and local peoples' connections with nature. Ecosyst. Serv. 2018, 31 Pt A, 111-125. [CrossRef]

23. Van der Ploeg, S.; de Groot, R. The TEEB Valuation Database-A Searchable Database of 1310 Estimates of Monetary Values of Ecosystem Services; Foundation for Sustainable Development: Wageningen, The Netherlands, 2010.

24. Jacquelin-Andersen, P. The Indigenous World 2018; International Work Group for Indigenous Affairs: Copenhagen, Denmark, 2018.

25. The United Nations. State of the World's Indigenous Peoples; Department of Economic and Social Affairs, Division for Social Policy and Development, Secretariat of the Permanent Forum on Indigenous Issues, United Nations Permanent Forum on Indigenous Issues (UNPFII): New York, NY, USA, 2009.

26. The United Nations Declaration on the Rights of Indigenous Peoples (UNDRIP). United Nations Declaration on the Rights of Indigenous Peoples; 61/295 Resolution adopted by the General Assembly on 13 September 2007; United Nations: New York, NY, USA, 2007.

27. Sangha, K.K. What Kind of Development We Want to Afford Sustainable Living? J. Environ. Sci. Eng. A 2018, 7, 34-48.

28. Settele, J.; Díaz, S.; Brondizio, E.; Daszak, P. COVID-19 Stimulus Measures: Must Save Lives, Protect Livelihoods, and Safeguard. Nature to Reduce the Risk of Future Pandemics, IPBES, Guest Article. 2020. Available online: https://ipbes.net/sites/default/files/2020-04/COVID19\%20Stimulus\%20IPBES\%20Guest\% 20Article_English.pdf (accessed on 2 May 2020).

29. Balasubramanian, M.; Sangha, K.K. Integrating Capabilities and Ecosystem Services Approaches to evaluate Indigenous connections with nature in a global biodiversity hotspot of Western Ghats, India. Ecosyst. Serv. 2020, submitted.

30. Sen, A. Development as Freedom; Oxford University Press: Oxford, UK, 1999. 
31. Barton, D.N.; Benavides, K.; Chacon-Cascante, A.; Le Coq, J.-F.; Quiros, M.M.; Porras, I.; Primmer, E.; Ring, I. Payments for Ecosystem Services as a Policy Mix: Demonstrating the institutional analysis and development framework on conservation policy instruments. Environ. Policy Gov. 2017, 27, 404-421. [CrossRef]

32. Díaz, S.; Settele, J.; Brondizio, E.; Ngo, H.T.; Pfaff, A.; Polasky, S.; Agard, J.; Arneth, A.; Balvanera, P.; Brauman, K.A.; et al. Investments role in ecosystem degradation-Response. Science 2020, 368, 377. [PubMed]

33. DasGupta, P. The Dasgupta Review_Independent Review on the Economics of Biodiversity (Interim Report); UK Government: London, UK, 2020; p. 81. Available online: https:/www.gov.uk/official-documents (accessed on 5 May 2020).

34. Australian Government. Working on Country. National Indigenous Australian Agency, Australian Government. 2020. Available online: https:/www.niaa.gov.au/indigenous-affairs/environment/indigenous-rangers-workingcountry (accessed on 5 September 2020).

35. Social Ventures Australia. Department of the Prime Minister E Cabinet: Consolidated Report on Indigenous Protected Areas following Social Return on Investment Analyses; SVA Consulting: Madison, WI, USA, 2016.

36. The Economics of Ecosystems and Biodiversity (TEEB). The Economics of Ecosystems and Biodiversity: Case Studies across the Globe. 2019. Available online: https://www.teebweb.org (accessed on 9 January 2020).

37. The United Nations. The Sustainable Development Goals Report 2016; United Nations: New York, NY, USA, 2016.

38. Veit, P.; Ding, H. Protecting Indigenous Land Rights Makes Good Economic Sense. World Resources Institute. 2016. Available online: https://www.wri.org/print/44554 (accessed on 4 May 2019).

(C) 2020 by the author. Licensee MDPI, Basel, Switzerland. This article is an open access article distributed under the terms and conditions of the Creative Commons Attribution (CC BY) license (http://creativecommons.org/licenses/by/4.0/). 